\title{
PEMBIAYAAN MUDHARABAH DAN PEMBIAYAAN MUSYARAKAH DI PERBANKAN SYARIAH
}

\author{
Chefi Abdul Latif \\ Akuntansi Syarieeah Fakultas Syarieeah dan Hukum \\ UIN Sunan Gunung Djati Bandung \\ Email : cal.alazfar@gmail.com
}

\begin{abstract}
ABSTRAK
Mudharabah adalah akad kerja sama pemilik modal dan pengelola modal dimana keuntungan dan kerugian dibagi berdasarkan kesepakatan oleh beberapa pihak yang terlibat. Musyarakah adalah akad kerjasama dua pihak atau lebih untuk berserikat dalam modal serta keuntungan dan kerugian yang diperoleh dibagi berdasarkan kesepakatan secara proporsional. Dasar hukum pembiayaan mudharabah dan pembiayaan musyarakah ada dalam al-Quran, Hadist, dan Ijma ${ }^{e e}$. Produk hukum yang mengatur kedua pembiayaan tersebut yaitu Perundang-undangan, Peraturan Bank Indonesia, Fatwa DSN MUI. Sebelum melaksanakan akad pembiayaan mudharabah dan musyarakah perlu diketahui dan diaktualisasikannya syarat dan rukun daripada kedua pembiayaan tersebut. Pembiayaan mudharabah terbagi menjadi dua bagian yaitu mudharabah muthlaqah dan mudharabah muqayyadah sedangkan Pembiayaan musyarakah terbagi kepada dua bagian, yaitu syirkah al-amlak dan syirkah al-,,uqud. Syirkah al-amlak terdiri dari, yaitu syirkah al-jabr dan syirkah al-ikhtiyar. Sedangkan syirkah al-,,uqud terdiri dari empat jenis, yaitu syirkah al-mufawadhah, syirkah al-,inan, syirkah al-wujuh, syirkah al"amal, dan syirkah mudharabah. Impelementasi pembiayaan mudharabah dan pembiayaan musyarakah diperbankan syariah sudah berkembang dan lengkap sesuai dengan peraturan perbankan syariah.
\end{abstract}

Kata kunci: Mudharabah, Musyarakah, Dasar Hukum, Produk Hukum, Rukun Dan Syarat, Pembagian Mudharabah Dan Musyarakah, Implementasi Mudharabah Dan Musyarakah Diperbankan Syariah. 


\section{PENDAHULUAN}

Lembaga Keuangan Syarieeah merupakan lembaga keuangan yang tidak hanya mengedepankan profit oriented saja, melainkan suatu lembaga keuangan yang mengedepankan kemaslahatan masyarakat sesuai dengan tuntutan syarieeah yang menjadi landasan dari semua lembaga keuangan syari"eah. ${ }^{1}$

Bank adalah badan usaha yang menghimpun dana dari masyarakat dalam bentuk simpanan dan menyalurkannya kepada masyarakat dalam bentuk kredit atau bentuk lainnya dalam rangka meningkatkan taraf hidup rakyat banyak. ${ }^{2}$

Bank syari"eah merupakan lembaga intermediasi dan penyedia jasa keuangan yang bekerja berdasarkan etika dan sistem Islam, khususnya yang bebas dari bunga (riba), bebas dari kegiatan spekulatif dan perjudian (maysir), bebas dari hal-hal yang tidak jelas (gharar), berprinsip keadilan, dan hanya membiayai kegiatan usaha yang halal kesemuanya merupakan prinsip-prinsip perbankan syarieeah.

Dalam memberikan pelayanan kepada masyarakat, perbankan syarie ah sudah semakin berkembang sebagai upaya memenuhi kebutuhan pasar. Mulai dari produk penghimpunan dana (funding), pembiayaan (landing), dan (service). ${ }^{4} \mathrm{Di}$ antara produk pembiayaan yang dikeluarkan Bank Syarie"ah Mandiri ialah pembiayaan mudharabah dan pembiayaan musyarakah.

Dalam konsep pembiayaan, Bank Syari"eah Mandiri dapat memberikan pembiayaan kepada nasabah berupa pembiayaan konsumtif, investasi, modal kerja, maupun kerja sama dalam sebuah proyek atau usaha. Pembiayaan yang dimplementasikan dalam kerjasama suatu usaha disebut pembiayaan mudharabah dan pembiayaan musyarakah.

Mudharabah berasal dari kata dharb, yang secara etimologis berarti bepergian atau berjalan. Al-Qurean tidak secara langsung menunjukan arti dari mudharabah tersebut. Namun secara implisit, kata dasar dha-ra-ba yang merupakan kata dasar mudharabah disebutkan di dalam AlQur'an sebanyak lima puluh delapan kali1. Wahbah Zuhayli menjelaskan salah satu arti dari mudharabah adalah melakukan perjalanan di muka bumi (al-sir fi al-ardh). ${ }^{5}$

Musyarakah berasal dari kata al-syirkah yang berarti al-ikhtilath (percampuran) atau persekutuan dua hal atau lebih, sehingga antara masing-masing sulit dibedakan. Seperti persekutuan hak milik atau perserikatan usaha. ${ }^{6}$

Dalam dunia usaha pada saat ini banyak pengusaha yang membutuhkan modal baik untuk mengembangkan dunia bisnisnya atau untuk memulai usaha/proyek baru. Hal ini menunjukan bahwa adanya akad pembiayaan mudharabah dan pembiayaan musyarakah di perbankan syariah begitu penting untuk menunjang usaha tersebut.

Akan tetapi, masih banyak orang belum tahu dan paham terkait akad pembiayaan mudharabah dan musyarakah itu bagaimana. Oleh karena itu, adanya artikel ini akan membahas terkait kedua pembiayaan. 


\section{PEMBAHASAN}

\section{Mudharabah}

Secara bahasa mudharabah diambil dari kata al-dharb fi al-Ardh, yang berarti perjalanan untuk berniaga. ${ }^{7}$ Pengambilan kata ini disebabkan amil dan mudharib meletakan mudharabah untuk bekerja dengan cara berniaga (tijarah) dan mencari keuntungan dengan permintaan dari pemilik modal ( $r a b$ al-mal).

Secara istilah, mudharabah berarti seorang malik atau pemilik modal menyerahkan modal kepada seorang amil untuk berniaga dengan modal tersebut, dimana keuntungan dibagi diantara keduanya dengan porsi bagian sesuai dengan yang dipersyaratkan dalam akad.

Jadi. Mudharabah adalah akad kerja sama pemilik modal dan pengelola modal dimana keuntungan dan kerugian dibagi berdasarkan kesepakatan oleh beberapa pihak yang terlibat.

\section{Dasar Hukum}

Mudharabah merupakan akad yang diperboleh berdasarkan :

\section{Al-Quran:}

“...Tidak ada dosa bagimu untuk mencari karunia (rezki hasil perniagaan) dari Tuhanmu". (Q.s. Al-Baqarah Ayat 198)

"Apabila telah ditunaikan shalat, Maka bertebaranlah kamu di muka bumi; dan carilah karunia Allah dan ingatlah Allah banyakbanyak supaya kamu beruntung". (Q.s AlJumu"eah Ayat 10)
Hadits:

"Diceritakan kepada kami Hasan bin Ali al-Khallal, diceritakan kepada kami Bisri bin Tsabit al-Bazzar, diceritakan kepada kami Nashr bin al-Qasim dari Abdurrahman bin Daud, dari Shalih bin Shuhaib r.a. bahwa Rasulullah saw. bersabda: "Tiga hal yang didalamnya terdapat keberkahan yaitu jual beli secara tangguh, muqaradhah (mudharabah), dan mencampur gandum dengan tepung untuk keperluan rumah, bukan untuk dijual." (HR Ibnu Majah no. 2280, kitab at-Tijarah). ${ }^{12}$

Ijma:

Diriwayatkan oleh sejumlah sahabat menyerahkan (kepada orang, mudharib) harta anak yatim sebagai mudharabah dan tidak seorangpun mengingkari mereka. Karenannya, hal itu dipandang sebagai ijmae ${ }^{\text {e. }}{ }^{13}$

\section{Produk Hukum}

Dalam konteks hukum, di Indonesia telah ditemukan beberapa produk yang berkaitan dengan mudharabah ini, baik dalam bentuk peraturan perundangundangan maupun dalam bentuk fatwa yang dikeluarkan oleh DSN (Dewan Syarieeah Nasional) Majelis Ulama Indonesia.

Berikut produk hukum yang mengatur tentang mudharabah diantaranya ialah

a. UU Nomor 10 Tahun 1998 menyebutkan mudharabah merupakan salah satu bentuk pembiayaan bagi hasil. 
b. UU Nomor 21 Tahun 2008 Pasal 1 ayat 21 disebutkan bahwa satu diantara tabungan ialah investasi dana berdasarkan akad mudharabah.

c. UU Nomor 21 Tahun 2008 Pasal 1 ayat 22 disebutkan bahwa deposito adalah investasi dana berdasarkan akad mudharabah.

d. UU Nomor 21 Tahun 2008 pasal 1 ayat 24 menyebutkan bahwa investasi adalah dana yang dipercayakan oleh nasabah kepada bank syarieeah dan/atau UUS berdasarkan akad mudharabah atau akad lain yang tidak bertentangan dengan prinsip syarieah dalam bentuk deposito, tabungan atau bentuk lainnya yang dipersamakan dengan itu.

e. UU Nomor 21 Tahun 2008 pasal 1 ayat 25 poin (a) menyebutkan bahwa pembiayaan adalah penyediaan dana atau tagihan yang dipersamakan dengan itu berupa transaksi bagi hasil dalam bentuk mudharabah dan musyarakah.

f. UU Nomor 19 Tahun 2008 tentang surat berharga syariecah negara pasal 1 ayat 7 disebutkan bahwa $m u$ dharabah adalah akad kerjasama antara dua pihak atau lebih, yaitu suatu pihak sebagai penyedia modal dan pihak lain sebagai penyedia tenaga dan keahlian, keuntungan dari kerjasama tersebut akan dibagi berdasarkan nisbah yang telah disetujui sebelumnya, sedangkan kerugian yang terjadi akan ditanggung sepenuhnya oleh pihak penyedia modal.

h. UU Nomor 19 Tahun 2008 pasal 3 disebutkan bahwa SBSN dapat berupa SBSN mudharabah, yang diterbitkan berdasarkan akad mudharabah.

i. PBI Nomor $7 / 24 / \mathrm{PBI} / 2004$ tentang Bank Umum yang kegiatan usaha berdasarkan prinsip syarie ah dan PBI Nomor 7/46/PBI/2005.

j. DSN MUI Fatwa Nomor 7 tentang pembiayaan mudharabah (Qiradh).

k. DSN MUI Fatwa Nomor 33 tentang Obligasi Syarieeah $\mathrm{Mu}$ dharabah.

1. DSN MUI Fatwa Nomor 38 tentang Sertifikat IMA

m.DSN MUI Fatwa Nomor 51 tentang Akad mudharabah musyarakah pada Asuransi Syarieeah.

n. DSN MUI Fatwa Nomor 59 tentang Obligasi Syarieah mudharabah

\section{Rukun dan Syarat Mudharabah}

Rukun adalah segala sesuatu yang menyebabka suatu akad dapat dilaksanakan, karena rukun adalah bagian integral yang tidak terpisahkan sehingga akad tersebut tidak rusak/batal (fasad) dalam pelaksanaannya. ${ }^{15}$ Berikut adalah rukun mudharabah menurut jumhur ulama:

a. Pihak-pihak yang melakukan akad, yaitu pemilik dana (shahibul maal) dan pengelola modal (mudharib)

b. Modal (Raesul Maal);

c. Usaha yang dijalankan (al-,,amal); 
d. Keuntungan (ribh); dan

e. Pernyataan ijab dan Kabul (sighat akad)

Sedangkan syarat mudharabah berkaitan dengan rukunnya, sebagai berikut :

a. Pihak-pihak yang melakukan akad mudharabah diisyaratkan harus memiliki kemampuan untuk dibebani hukum/cakap hukum (mukallaf) untuk melakukan kesepakatan, dalam hal ini pemilik modal (shahibul maal) akan memberikan kuasa dan pengelola modal (mudharib) menerima kuasa tersebut, karena di dalam akad mudharabah terkandung akad wakalah/Kuasa.

b. Modal (Raeesul Maal) dalam akad mudharabah harus memenuhi kententuan sebagai berikut:

a) Modal harus berupa alat tukar (uang);

b) Modal harus diketahui sehingga mudah untuk diukur;

c) Modal harus dalam bentuk tunai; dan

d) Modal harus dapat dipindahkan/diserahkan dari pemilik modal (shahibul maal) kepada pengelola modal (mudharib).

\section{Pembagian Mudharabah}

Akad mudharabah dibedakan menjadi dua: 1) mudharabah-muthlaqah (mudharabah tidak terikat/bebas); dan 2) mudharabahmuqayyadah (mudharabah terikat). Wahbah al-Zuhaili menegaskan bahwa yang dimaksud dengan akad mudharabah tidak terikat adalah penyerahan modal dari shahibul al-mal kepada mudharib untuk melakukan usaha (bisnis) tanpa ditentukan jenis usahanya, tempatnya, waktunya, sifat bisnisnya, dan/atau pihak yang melakukan usahanya. Sedangkan mudharabah terikat adalah akad mudharabah yang berupa penyerahan modal dari shahibul almal kepada mudharib untuk melakukan usaha (bisnis) yang ditentukan jenis usahanya, tempatnya, waktunya, sifat bisnisnya, dan/atau pihak yang melakukan usahanya.

Implementasi Mudharabah di Perbankan Syarieeah dan BMT Implementasi mudharabah di perbankan syarieeah terbagi menjadi dua bagian, yaitu pada saat pengerahan dana dan pada saat penyaluran dana. Pengerahan dana merupakan mekanisme masuknya dana dari nasabah kepada bank, sedangkan penyaluran dana merupakan keluarnya dana dari bank kepada nasabah.

Pada saat pengerahan dana mudharabah di implementasikan dalam bentuk tabungan mudharabah dan deposito mudharabah. Tabungan mudharabah merupakan dana nasabah yang disimpan akan dikelola oleh bank untuk mendapatkan keuntungan dengan mekanisme nisbah berdasarkan kesepakatan bersama. Deposito mudharabah adalah dana simpanan nasabah yang hanya bisa ditarik berdasarkan jangka waktu yang telah ditentukan, serta nasabah berhak ikut menanggung keuntungan dan kerugian yang dialami bank sebagai pengelola dana.

Penyaluran dana, yaitu dalam bentuk pembiayaan mudharabah. Pembiayaan $m u$ dharabah adalah bank menyediakan pem- 
biayaan modal investasi atau modal kerja secara penuh (trusty financing), sedangkan nasabah menyediakan proyek atau usaha lengkap dengan manajemennya. Hasil keuntungan dan kerugian yang dialami nasabah dibagi atau ditanggung bersama antara bank dan nasabah dengan ketentuan sesuai kesepakatan bersama.

\section{Musyarakah}

Secara bahasa musyarakah sering pula disebut dengan syirkah yang bermakna ihktilath (pencampuran), yakni bercampurnya salah satu dari dua harta dengan harta lainnya tanpa dapat dibedakan diantara keduanya. ${ }^{21}$ Musyarakah juga bisa berarti seseorang mencampur hartanya dengan harta orang lain dengan mana salah satu pihak tidak menceraikan dari yang lainnya.

Secara terminologi, musyarakah berarti akad di antara dua orang atau lebih untuk berserikat dalam modal dan keuntungan. Musyarakah adalah akad kerjasama yang terjadi di antara para pemilik modal (mitra musyarakah) untuk menggabungkan modal dan melakukan usaha secara bersama dalam suatu kemitraan, dengan nisbah pembagian hasil sesuai dengan kesepakatan, sedangkan kerugian ditanggung secara proporsional sesuai dengan kontribusi modal.

Dari ketiga definisi diatas bahwa musyarakah adalah akad kerjasama dua pihak atau lebih untuk berserikat dalam modal serta keuntungan dan kerugian yang diperoleh dibagi berdasarkan kesepakatan secara proporsional.

Dasar Hukum
Musyarakah adalah akad yang diperbolehkan berdasarkan Al-Quran, Hadist dan Ijma"e

Menurut Al-Quran Q.S. An Nisa Ayat 12

"Tetapi jika saudara-saudara seibu itu lebih dari seorang, maka mereka bersekutu dalam yang sepertiga itu"

Q.S. Shaad Ayat 24:

"Dari sesungguhnya kebanyakan dari orang-orang yang berserikat itu sebagian mereka berbuat zalim kepada sebagian yang lain, kecuali orang-orang yang beriman dan mengerjakan amal yang shaleh; dan amat sedikitlah mereka ini".

Hadits

Berikut adalah hadist-hadist tentang musyarakah:

"Allah swt, berfirman: Aku adalah pihak ketiga dari orang yang berserikat selama satu pihak tidak mengkhianati pihak yang lain."

"Jika sala satu pihak telah berkhianat, aku keluar dari mereka. (HR. Abu Daud dari Abu Hurairah). ${ }^{25}$

Ijma

Ibnu Qudamahdalam kitabnya, al Mughni, telah berkata: "Kaum muslimin telah berkonsensus terhadap legitimasi masyarakat secara global walaupun terdapat perbedaan pendapat dalam beberapa elemen darinya" 26

\section{Produk Hukum}

Dalam konteks hukum, di Indonesia telah ditemukan beberapa produk yang berkaitan dengan musyarakah ini, baik 
dalam bentuk peraturan perundangundangan maupun dalam bentuk fatwa yang dikeluarkan oleh DSN (Dewan Syarieeah Nasional) Majelis Ulama Indonesia.

Berikut produk hukum yang mengatur tentang musyarakah diantaranya ialah:

a. UU Nomor 10 Tahun 1998 menyebutkan musyarakah merupakan salah satu bentuk pembiayaan bagi hasil.

b. UU Nomor 21 Tahun 2008 pasal 1 ayat 25 disebutkan bahwa pembiayaan merupakan penyediaan dana atau tagihan yang samanya dengan transaksi nisbah dalam bentuk mudharabah dan musyarakah.

c. UU Nomor 19 Tahun 2008 tentang SBSN menyebutkan musyarakah.

d. UU Nomor 19 Tahun 2008 pasal 1 ayat 7 menyebutkan bahwa musyarakah adalah akad kerjasama antara dua orang atau lebih untuk menggabungkan modal, baik dalam bentuk uang maupun dalam bentuk lainnya, dengan tujuan memperoleh keuntungan, yang akan dibagikan sesuai dengan nisbah yang telah disepakati sebelumnya, sedangkan kerugian yang timbul akan ditanggung bersama sesuai dengan jumlah partisipasi modal masing-masing pihak.

e. PBI Nomor 7/46/PBI/2005 tentang akad penghimpunan dan penyaluran dana bagi bank yang melaksanakan kegiatan usaha berdasarkan prinsip syarie $a h$. f. DSN MUI Fatwa Nomor 8 tentang pembiayaan musyarakah.

g. DSN MUI Fatwa Nomor 55 tentang pembiayaan rekening Koran syarieah musyarakah.

h. DSN MUI Fatwa Nomor 73 tentang musyarakah mutanaqisah.

Syarat dan Rukun Musyarakah

Adapun syarat syirkah adalah sebagai berikut :

a. Tidak ada bentuk khusus kontrak, berakad dianggap sah jika diucapkan secara verbal/tertulis, kontrak dicatat dalam tulisan dan disaksikan.

b. Mitra harus kompeten dalam memberikan/diberikan kekuasaan perwalian.

c. Modal harus uang tunai, emas, perak yang nilainya sama, dapat terdiri dari asset perdagangan, hak yang tidak terlihat (misalnya lisensi, hak paten dan sebagainya).

d. Partisipasi para mitra dalam pekerjaan adalah sebuah hukum dasar dan tidak diperbolehkan bagi salah satu dari mereka untuk mencantumkan tidak ikut sertanya mitra lainnya. Namun porsi melaksanakan pekerjaan tidak perlu harus sama, demikian pula dengan bagian keuntungan yang diterima.

Adapun Rukun syirkah adalah sebagai berikut :

a. Ijab-qabul (sighat) Adalah adanya kesepakatan antara kedua belah pihak yang bertransaksi. 
b. Dua pihak yang berakad (aqidani) dan memiliki kecakapan melakukan pengelolaan harta.

c. Objek aqad (mahal), yang disebut juga maequd alaihi, yang mencakup modal atau pekerjaan.

d. Nisbah bagi hasil.

Secara umum, musyarakah terbagi kepada dua bagian, yaitu syirkah al-amlak dan syirkah al-„,uqud. Syirkah al-amlak itu sendiri terbagi kepada dua bagian besar, yaitu syirkah al-jabr dan syirkah al-ikhtiyar. Sedangkan syirkah al-,,uqud terdiri dari empat jenis, yaitu syirkah al-mufawadhah, syirkah al-,,inan, syirkah al-wujuh, syirkah alamal, dan syirkah mudharabah. ${ }^{31}$

Berikut adalah penjelasan dari setiap syirkah-syirkah yang ada:

a. Syirkah al-amlak

Syirkah al-amlak (syirkah milik) adalah ibarat dua orang atau lebih memilikkan suatu benda kepada yang lain tanpa ada akad syirkah.

a) Syirkah al-jabr, yaitu berkumpulnya dua orang atau lebih dalam pemilikan suatu benda secara paksa.

b) Syirkah al-ikhtiyar, yaitu suatu bentuk kepemilikan bersama yang timbul karena perbuatan orang-orang yang berserikat.

b. Syirkah al-uqud

Syirkah al-uqud (contractual partnership), dapat dianggap sebagai kemitraan yang sesungguhnya, karena para pihak yang bersangkutan secara sukarela berkeinginan untuk membuat suatu perjanjian investasi bersama dan berbagi untuk dan risiko.

a) Syirkah al-mufawadhah; Yaitu akad kerja sama usaha antar dua pihak atau lebih, yang masingmasing pihak harus menyerahkan modal dengan porsi modal yang sama dan bagi hasil atas usaha atau risiko ditanggung bersama dengan jumlah yang sama. Dalam syirkah mufawwadah, masingmasing mitra usaha memiliki hak dan tangung jwab yang sama.

b) Syirkah al-,,inan

Yaitu akad kerja sama usaha antara dua orang atau lebih, yang masingmasing mitra kerja harus menyerahkan dana untuk modal yang porsi modalnya tidak harus sama. Pembagian hasil usaha sesuai dengan kesepakatan, tidak harus sesuai dengan kontribusi dana yang diberikan. Dalam syirkah inan, masing-masing pihak tidak harus menyerahkan modal dalam bentuk uang tunai saja, akan tetapi dapat dalam bentuk aset atau kombinasi antara uang tunai dan asset atau tenaga.

c) Syirkah al-wujuh

Yaitu dua orang atau lebih membeli suatu barang tanpa modal, melainkan semata berdagang kepada nama baik dan kepercayaan pada pedagang kepada mereka. Syirkah ini disebut juga syirkah tanggung jawab tanpa kerja dan modal. ${ }^{38}$

d) Syirkah al-,,amal 
Yaitu kontrak kerja sama dua orang seprofesi untuk menerima pekerjaan secara bersama dan berbagi keuntungan dari pekerjaaan itu. Misalnya kerja sama dua orang arsitek untuk menggarap sebuah proyek atau kerjasama, dua orang penjahit untuk menerima order pembuatan seragam sebuah kantor. Musyarakah ini kadang disebut dengan syirkah abdan atau sanaa" $i .39$

e) Syirkah mudharabah

Yaitu kerja sama usaha antara dua pihak atau lebih yang mana satu pihak sebagai shahibul maal yang menyediakan dana 100\% untuk keperluan usaha, dan pihak lain tidak menyerahkan modal dan hanya sebagai pengelola atas usaha yang dijalankan, disebut mudharib.

\section{Implementasi Musyarakah}

\section{di Perbankan Syarieeah dan BMT}

Musyarakah dalam konteks perbankan berarti perjanjian kesepakatan bersama antara beberapa pemilik modal untuk menyertakan modal sahamnya pada suatu proyek. Berkorelasi dengan modal, bank umum sebagai yang mengoperasikan uang sebagai modal, maka dapat dipastikan musyarakah yang digunakan ialah syirkah al-mal yakni syirkah al-inan dan syirkah al-mufawadhah.

Namun, prinsipnya ialah perbankan syarieah tidak menentukan harus sama dengan permodalan, maka bisa dipertanggung jawabkan bahwa musyarakah yang digunakan oleh perbankan syarieeah adalah syirkah al-inan. ${ }^{42}$
Berikut merupakan beberapa ketentuan yang wajib menjadi perhatian dalam melaksanakan musyarakah dalam perbankan syarieeah, ialah :

a. Pembiyaan suatu usaha investasi yang telah menemui kesepakatan dan disetujui dilakukan bersamasama dengan mitra usaha yang lain sesuai dengan bagian masingmasing yang telah ditetapkan.

b. Semua pihak yang telibat, termasuk bank syarieeah memiliki hak dalam manajemen usaha tersebut.

c. Seluruh pihak secara seksama menentukan posisi keuntungan yang akan diperoleh, pembagiannya disesuaikan dengan penyertaan modal masing-masing.

d. Bila proyek ternyata rugi, maka semua pihak ikut menanggung kerugian sebanding dengan penyertaan modal.

Aturan operasional akad musyarakah di perbankan syarieeah terlaksana pada penyaluran dana, dimana produknya disebut dengan pembiayaan musyarakah, yakni penyertaan modal yang diberikan oleh bank syariecah kepada nasabah yang telah memiliki sebagian modal. Dalam pelaksanaanya, akad musyarakah diawali dengan pengajuan pembiayaan dari nasabah kepada bank. Kemudian, bank merealisasikan pengajuan nasabah tersebut dan berinvestasi sesuai dengan jumlah modal yang diperlukan nasabah. Perhitungan investasi modal yang diberikan bank secara proporsional dengan modal yang dimiliki nasabah. Terakhir, nasabah 
melaksanakan proyek dengan gabungan modal tersebut.

Menurut PBI, dalam melaksanakan musyarakah tersebut ditetapkan dengan beberapa syarat, sebagai berikut:

a. Bank dan nasabah masing-masing bertindak sebagai mitra usaha bersama dengan menyediakan modal dan/atau barang untuk membiayai opersional usaha tersebut;

b. Nasabah bertindak sebagai pengelola proyek sedangkan bank bertindak sebagai mitra usaha dengan berhak mengelola manajemen;

c. Berdasarkan kesepakatan bank dan nasabah, bank berhak menunjuk nasabah untuk mengelola usaha;

d. Pembiayaan diberikan dalam bentuk tunai dan/atau barang

e. Dalam hal pembiayaan diberikan dalam bentuk barang, maka barang yang diserahkan harus dinilai secara tunai berdasarkan kesepakatan;

f. Jangka waktu pembiayaan, pengembalian dana, dan pembagian keuntungan ditentukan berdasarkan kesepakatan antara bank dan nasabah;

g. Biaya operisional dibebankan pada modal bersama sesuai kesepakatan;

h. Pembagian keuntungan dari pengelola dana dinyatakan dalam bentuk nisbah disepakati;

i. Bank dan nasabah menanggung kerugian secara proporsional menurut porsi modal masing-masing, kecuali terjadi kecurangan, lalai, atau menyalahi perjanjian dari salah satu pihak;

j. Nisbah bagi hasil yang disepakati tidak dapat diubah sepanjang jangka waktu investasi, kecuali atas dasar kesepakatan para pihak dan tidak berlaku surut;

k. Nisbah bagi hasil dapat ditetapkan secara berjenjang (tiering) yang besarnya berbeda-beda berdasarkan kesepakatan pada awal akad;

1. Pembagian keuntungan dapat dilakukan dengan metode bagi untung atau rugi (profit and loss sharing) atau metode bagi pendapatan (revenue sharing);

m.Pembagian keuntungan berdasarkan hasil usaha sesuai dengan laporan keuangan nasabah;

n. Pengembalian pokok pembiayaan dilakukan pada akhir periode akad atau dilakukan secara angsuran berdasarkan aliran kas masuk (cash in flow) usaha; dan

o. Bank dapat meminta jaminan atau agunan untuk mengantisipasi risiko apabila nasabah tidak dapat memenuhi kewajiban sebagaimana dimuat dalam akad karena kelalaian dan atau kecurangan.

\section{SIMPULAN}

Mudharabah adalah akad kerja sama pemilik modal dan pengelola modal dimana keuntungan dan kerugian dibagi berdasarkan kesepakatan oleh beberapa pihak yang terlibat. Pihak-pihak yang melakukan akad mudharabah diisyaratkan 
harus memiliki kemampuan untuk dibebani hukum/cakap hukum (mukallaf) untuk melakukan kesepakatan. Modal harus berupa alat tukar (uang), Modal harus diketahui sehingga mudah untuk diukur, Modal harus dalam bentuk tunai, dan Modal harus dapat dipindahkan/diserahkan dari pemilik modal (shahibul maal) kepada pengelola modal (mudharib).

Tidak ada bentuk khusus kontrak, berakad dianggap sah jika diucapkan secara verbal/tertulis, kontrak dicatat dalam tulisan dan disaksikan. Mitra harus kompeten dalam memberikan/diberikan kekuasaan perwalian. Modal harus uang tunai, emas, perak yang nilainya sama, dapat terdiri dari asset perdagangan, hak yang tidak terlihat (misalnya lisensi, hak paten dan sebagainya).

Partisipasi para mitra dalam pekerjaan adalah sebuah hukum dasar dan tidak diperbolehkan bagi salah satu dari mereka untuk mencantumkan tidak ikut sertanya mitra lainnya. Namun porsi melaksanakan pekerjaan tidak perlu harus sama, demikian pula dengan bagian keuntungan yang diterima.

Pembiayaan musyarakah terbagi kepada dua bagian, yaitu syirkah al-amlak dan syirkah al-„uqud. Syirkah al-amlak itu sendiri terbagi kepada dua bagian besar, yaitu syirkah al-jabr dan syirkah al-ikhtiyar. Sedangkan syirkah al-,,uqud terdiri dari empat jenis, yaitu syirkah al-mufawadhah, syirkah al-,,inan, syirkah al-wujuh, syirkah al"amal, dan syirkah mudharabah.

Musyarakah dalam konteks perbankan berarti perjanjian kesepakatan bersama antara beberapa pemilik modal untuk menyertakan modal sahamnya pada suatu proyek. Sebagai yang mengoperasikan uang untuk modal, maka dapat dipastikan musyarakah yang digunakan ialah syirkah al-mal yakni syirkah al-inan dan syirkah al-mufawadhah. 


\section{DAFTAR PUSTAKA}

\section{BUKU}

Abd al-Sattar Abu Ghada, Buhuts fi al-Mu "amalat wa al-Asalib al-Masharifiyah al-Islamiyah (t.t: Majmu eeah Dilah al-Barkah.2003).

Abdul Aziz Dahlan, dkk. (Ed), Ensiklopedia Hukum Islam (Jakarta: Ichtiar Baru Van Hoeve, 1997), 195. Bandingkan pula dengan Karnaen A. Perwataatmadja dan Syafie I Antonio, Apa dan Bagaimana Bank Islam (Yogyakarta: Dana Bhakti Wakaf, 1992).

A. Djazuli dan Yadi Janwari, Lembaga-Lembaga Perekonomian Umat, (Jakarta : Raja Grafindo Persada, 2002).

Abdul Ghafar Anshori, Hukum Perjanjian Islam Di Indonesia (konsep, regulasi, dan implementasi), (Yogyakarta: Gadjah Mada University Press).

Ahmad Wardi Muslich, Fiqh Muamalat, (Jakarta: Amzah, cet ke-1, 2010). Al-Zuhaili, alFigh al-Islami, hlm. 3928; dan lihat Umar Mushthafa Jabar Isma" il. Andri, Soemitra, Bank dan Lembaga Keuangan Syariah, (Jakarta: Kencana Prenada Media Group, 2009).

Ascarya, Akad dan Produk Bank Syariah, Jakarta: Rajawali Press, 2001.

Departemen Agama RI, Al-Qur"an dan Terjemahnya, Bandung: Syaamil Qur"an, 2012

Ghufron A.Maseeadi, Fiqh Muamalah Kontekstual, (Jakarta: PT RajaGrafindo Persada, cet ke-1), 2002

Hendi Suhendi, Fiqh Muamalah,( Jakarta: Rajawali Pers, 2010).

Ismail, Perbankan Syariah, (Jakarta: Kencana Prenadamedia Group).

Janwari, Yadi. 2015. Fikih Lembaga Keuangan Syariah. Bandung : PT Remaja Rosdakarya.

Kamsir, Dasar-dasar perbankan, (Jakarta:Raja Grafindo Persada, 2013).

Luis Ma'luf, al-Munjid fi al-Lughah wa al-A "lam, (Beirut: Dar al-Masyriq, 1986).

Mardani, Hukum Bisnis Syariah, (Jakarta: Prenadamedia Group, cet ke-1, 2014).

Muhammad Syafiei Antonio, Bank Syariah: Dari Teori ke Praktek, (Jakarta:

Gema Insani, cet ke-1, 2010).

Nafean, Pembiayaan Musyarakah dan Mudharabah, (Yogyakarta: Graha Ilmu, cet ke-1, 2014).

Rozalinda, Fikih Ekonomi Syarieeah (Jakarta: PT Rajagrafindo Persada, 2016).

Sanadat al-Muqaradhah wa Ahkamuha fi al-Figh al-Islami: Dirasah Muqaranah Thatbiqiyyah (Ammam:Dar al-Nafa"eis. 2006).

Sayyid Sabiq, Fiqh al-Sunnah (Beirut: Dar al-Kitab al-„,Arabiyyah, 1973). 
Veithzal Rivai, Islamic Banking, (Jakarta: Sinar Grafika Offset, 2010). Wahbah al-Zuhayli, al-Fiqh al-Islami wa Adilatuh (Beirut: al-Kutub, 1989). Wahbah Zuhaily, Fiqih Islam 7 , diterjemahkan oleh Abdul Hayyie al- Kattani, dkk dalam "al-Fiqh al-Islam wa Adilatuhu", Damaskus, Darul Fikr, jilid IV, 1989.

Wahbah Az-Zuhayli, Figh Islam Wa Adillatuhu.(Jakarta:Gema Insani,2007).

\section{JURNAL}

Jurnal musyarakah, BAB II Landasan Teori. diakses pada tanggal 8 Januari 2020.

\section{PERATURAN}

Undang-Undang Nomor 10 Tahun 1998 tentang Perbankan.

Peraturan Bank Indonesia Nomor 7/46/PBI/2005 tentang Akad Penghimpunan dan Penyaluran Dana bagi Bank yang Melaksanakan Kegiatan Usaha Berdasarkan Prinsip Syariah.

\section{INTERNET}

https://ojk.go.id/id/kanal/syariah/berita-dankegiatan/publikasi/Documents/Pages/BukuStandarProduk-Mudharabah-

Seritandar-Produk-Perbankan-

Syariah5/BUKU\%20Standar\%20Produk\%20Mudharabah.PDF, diakses pada tanggal 8 Januari 2020.

https://media.neliti.com/media/publications/267914-mudharabah-murabahah-dan-

musyarakah-peng-dee95320.pdf [Siti Fauziah] diakses pada tanggal 8 Januari 2020 https://www.ojk.go.id/id/kanal/syariah/berita-dan-

kegiatan/publikasi/Documents/Pages/Buku-Standar-Produk-Musyarakah-dan-

Musyarakah-

Mutanaqishah/Buku\%20Standar\%20Produk\%20Musyarakah\%20dan\%20Musyarakah\% 20Mutanaqishah.pdf [standar produk musyarakah]diakses pada tanggal 8 januari 2020

http://digilib.uinsgd.ac.id/21020/5/5_bab2.pdf diakses pada tanggal 10 Januari 2020 http://eprints.walisongo.ac.id/3789/3/102311070_Bab2.pdf diakses pada tanggal 10 Januari 2020

http://repository.uma.ac.id/bitstream/123456789/1073/5/128330028_file5.pdf diakses pada tanggal 10 Januari 2020

http://repository.usu.ac.id/bitstream/handle/123456789/65580/Chapter\%20II.pdf?

sequence $=4 \&$ isAllowed $=y$ diakses pada tanggal 10 Januari 2020

http://repository.unpas.ac.id/15466/4/BAB\%20II\%20fix\%20.pdf diakses pada tanggal 10 Januari 2020 
chefi abdul latif 